\title{
Education, Sexuality and Anti-gender Movements in Latin America'
}

\section{Anelise Gregis Estivalet, Gabriel Dvoskin}

\begin{abstract}
This article analyses the discourses of anti-gender movements circulating in Brazil and Argentina. The aim of our research is to determine the regularities and specificities of these movements. Specifically, it analyses the representations that are mobilised in the political sphere about gender and sexuality and the role that is attributed to the school institution in these matters. Therefore, an analysis is made of the discussion relating to legislative bills and the parliamentary debates that took place on the Escola Sem Partido (ESP) in Brazil between 2014 and 2017 and on the Interrupción Voluntaria del Embarazo (IVE) in Argentina in 2018. The focus here is exclusively on the discourse employed in favour of the ESP project in Brazil and against the IVE in Argentina, since the ESP and the IVE are opposed to the expansion of rights relating to gender and sexuality. Finally, we concluded that the anti-gender discourse in these countries shares with the religious discourse its precepts relating to gender and sexuality issues. However, the current discourse of this movement is not positioned grounded in religious discourse. Instead, it appeals to scientific and legal discourses as a mechanism of establishing legitimacy and as a way of attracting a wider audience.
\end{abstract}

Keywords: sex education, anti-gender movements, Latin America

Gregis Estivalet, Anelise, Dvoskin, Gabriel. 2021. Education, Sexuality and Anti-gender Movements in Latin America. Gender a výzkum / Gender and Research 22 (2): 28-44, http://dx.doi.org/10.13060/gav.2021.018.

During the last decade of the twentieth century and the first decade of the twentyfirst, we saw gender and sexuality policies beginning to be addressed in a transnational context, among democracies in Europe, North America and Latin America. We observed this not only in the bigger space that they were being given in the mass media and in the emergence of new social groups that focused their demands on

\footnotetext{
1 We appreciate the comments of the reviewers, who enriched the content of this article and our epistemological perspectives.
} 
these issues - such as the 'Ni Una Menos' and 'Me Too' movements, which emerged in South America and the United States, respectively, but also in the adoption and implementation of laws and public policies relating to these issues (Careaga Perez 2019; Tabbush et al. 2020).

The circulation of these issues in the public sphere gave visibility to discussions about the material and symbolic inequalities that affect gender differences, which were previously silenced or relegated to very restricted areas (Radi, Pagani 2021). In the first stage, these inequality claims were usually associated with health issues, cases of abuse, or physical violence. However, nowadays there are also aspects of gender and sexuality that are linked to identity, pleasure, and autonomy (Dvoskin 2021).

The greater prominence of these issues on the social and political agenda ${ }^{2}$ was met with the (re)emergence of anti-gender movements (Kuhar, Zobec 2017; Morán Faúndes 2017; Pérez, Moragas 2020). These movements ${ }^{3}$ questioned the advances in sexual and reproductive rights that had been achieved in recent decades, such as the legalisation or push for marriage equality in France, Argentina, Brazil, Colombia, Mexico, and Uruguay, the inclusion of sexuality as a mandatory topic in educational curricula in different Latin American countries, and the legalization of abortion (Argentina, Colombia, Uruguay). The nature of the opposition to these developments varies according to the country or region in which it is manifested or according to the specific issue in question, but the main argument that movements of this type articulate $^{4}$ is their refusal to allow the state to intervene in people's private lives (Campana 2020; Vaggione 2013).

This argument is most famously levelled when the discussion is about sex education in schools. In these cases, the expression 'gender ideology' is used as a sign that encapsulates a variety of meanings that question and reject the implementation of this kind of politics (Kováts, Põim 2015). The inclusion of sexuality as a compulsory topic

\footnotetext{
2 As we will see throughout this article, the great notoriety of these issues both at a social and political dimension was manifested, on one hand, in the sanctioned public policies and, on the other, in the diversity of social movements that dealt with the treatment of these issues. For a more detailed development, it can be read Felitti, Prietto (2018).

${ }^{3}$ The speech about "gender ideology" gained strength in Europe after the publication of the book "Lexicon", in 2003. Different manifestations started to appear, first in Spain in 2004 and, later, in countries like Croatia (2006), Italy (2007) and Slovenia (2009). The year 2012 was, then, the watershed of these movements that started to acquire a character of mass mobilizations. Between 2012 and 2017, several protests were recorded in France (2012-2013), Italy (2013), Slovenia (2014-2015), Croatia (2013), Slovakia (2015) and Romania (2017). With regard to the topic of sex education in schools, dates from 2006, the start of a discussion in Croatia on the topic (Kuhar 2015). Similarly, discussions began in 2011, in France, about the inclusion of gender in textbooks (Béraud 2015).

${ }^{4}$ We are aware that the movements that oppose these types of policies do not constitute a homogeneous group. However, in this research we are interested in focusing on the aspects that articulate their differences, so that they are presented as a unified discourse.
} 


\section{NV STATI / ARTICLES}

in educational curricula opens discussions not only about gender and sexuality but also about what social functions the school as an institution should fulfil in modern Western societies (Lopes Louro 2018).

In this article, we decided to analyse the discourses of the anti-gender movements in Brazil and Argentina, focusing on the period between 2014 and 2018.

This article is organised as follows: In the next section, we will provide a brief history of the term 'gender ideology' and the sex education policies that have been introduced in Latin America, and describe how the main opposition movements have responded. In the sections after that, we will present the epistemological framework for our investigation and the analysis of the corpus. The last section of the article is devoted to final considerations and possible lines of further investigation.

\section{Theoretical framework}

\section{Gender ideology?}

In Latin America, the use of 'gender ideology' as an oppositional term has been around since the late 1990s in countries such as Peru, Costa Rica and Colombia. In the case of Argentina, the term has been in use (in this way) since the first half of the 2000s, while in Brazil the term was rarely used until 2007 (Corrêa, Kalil 2020). In Europe, 'gender ideology', which in some countries is called 'gender theory' or 'genderismus' (German-speaking countries), connotes much more than just resistance to egalitarian marriage. Because it is never clearly defined, its meaning is hard to pin down, which makes using it easier for different movements linked, in most cases, to the extreme right. The impression that results from this kind of use is that it is alluding to some kind of conspiracy theory a conspiracy theory. 'Gender ideology' thereby functions as an 'empty signifier' (Mayer, Sauer 2017) that can be claimed to be anything and everything, from marriage equality and sex education to reproductive rights and abortion (Kuhar, Zobec 2017). The term has been used in different countries as a political tool to generate fear based on false information and on a distortion of what kind of teaching around gender is going on in schools. For Junqueira (2016: 230), gender ideology is, therefore, a powerful slogan, one that in many countries can ignite the political arena and spark violent demonstrations against social policies, legal reforms, and teaching activities aimed at promoting sexual rights and punishing the violations of such rights, and at fighting prejudice, preventing violence, and combatting (hetero) sexist discrimination.

In this sense, we can identify at least two discursive strategies that are used to establish what we call 'moral panic': the first is the symbolic binder and the second is the empty signifier (Laclau 2013). Kuhar and Zobec (2017), who analysed European cases in which 'gender' was construed in multi-dimensional ways as the enemy, note 
that the term ends up being shaped in different ways to fit the concrete objective of a political protest. Thus, when the concept of gender, developed in the academic world by feminist studies, is introduced into a conservative or ultra-conservative political space it loses its scientific character and is made it into something that in itself does not mean anything and is, therefore, liable to mean anything, depending on what kind of political attack someone wants to make against this or that opponent. A new narrative is then constructed from a symbolic binder. With that, other expressions or triggers that can help in creating a moral panic (Barzotto, Seffner 2020: 156) are assigned and attached to the concept of 'gender'.

These discourses strengthen the sense of moral panic, which serves as a mechanism of resistance to educational and pedagogical materials that provide information about sexually transmitted diseases, social inequalities, gender issues, homophobia, feminicide, racism, and drug use (licit and illicit). Therefore, the term 'gender ideology', which in itself is devoid of meaning, is inflated as a way of establishing this generalised moral panic (Moura, Silva 2020: 275).

When this strategy is used, religious discourse starts to compete with science and to oppose and disqualify scientific discourse. This creates a clash between religion and science: this religious discourse uses a language that implies common sense, and simplistic dichotomies that reduce complex issues to false alternatives and draw on existing polarisations in the political field to introduce and reinforce them in the educational field (Penna 2017: 35).

According to Kóváts and Põim (2015: 14), the phrase 'gender ideology' did not originate in extreme right-wing movements but they easily adopted it. Economic crises and austerity measures have encouraged anti-gender protests, not only in Europe but also in America; these movements arise out of people's unhappiness about corruption among the elites and people then end up attacking minority rights and using minorities as scapegoats. Although these actors may not be aware of the religious origins of the term 'gender ideology', the discourse around this term often resonates with their own ideas and criticisms of gender. This may include efforts to overthrow the legacy of May ' 68 or to defend national sovereignty against neocolonial interference from Western Europe or the United States.

Thus, anti-gender movements use these discursive strategies (Wodak 2015) as a tool for far-right rhetoric in which the victim and perpetrator are reversed, minorities are used as scapegoats, and conspiracy theories are constructed and shared. Their policy depends on the 'politics of fear' and the 'arrogance of ignorance'. From a binary and antagonistic 'us' and 'them' perspective, this ideology considers the existence of two groups in society: the 'pure people' and the 'corrupt elites' (Mudde 2007).

The term 'gender ideology' has been defined as 'a sombre ending that creates a common sense capable of reaching a large audience' (Amaya 2017: 160-161). 


\section{NV STATI / ARTICLES}

What danger 'gender ideology' can be deemed to represent for a given society can be adapted to different countries or regions by employing various statements that generate unease and stir up the public. We can mention cases in which the term has been associated with 'communism' in Russia and Germany, 'pedophilia' in Poland, colonial domination in Hungary, 'Islam' in Austria, and with the FARCs in Colombia (Kováts, Põim 2015; Careaga Pérez 2019). In the case of Brazil, it is associated not only with 'communism' but also with a mass-produced fake news report during the 2018 elections that claimed the candidate of the Partido dos Trabalhadores (PT), Fernando Haddad, would be distributing baby bottles with phallic-shaped nipples at daycare centres as part of a plan to 'destroy the family'. Miguel (2016) notes that the position of the anti-gender movement can be defined as supporting the authoritarian primacy of the rights of parents over the republican rights of students, as the parents' freedom of right to make decisions about their children is deemed more important than the children's freedom to right to an education. We can see proof of Miguel's claim in the slogan of one such movement, which is 'my children, my rules' (Penna 2017). In this sense, there is an emptying of public law in the face of private law, and the phrase 'gender ideology' is employed in a proclaimed effort to 'protect children' from certain danger.

\section{Sex education and anti-gender movements: the Latin American case}

In Latin American countries, sex education has been part of the social and political agenda as a discussion topic for decades (Faur 2012; Morgade 2017). Those who support its inclusion in the school curriculum base their position on a human rights paradigm, which incorporates an integral view of sexuality and a gender perspective paradigm. However, the actions and policies that have been implemented in these countries have had many different effects. Báez and González del Cerro (2015) note how these measures are framed in different ways: prevention prevention of sexually transmitted diseases and teenage pregnancy as a fundamental right, on one hand; and the problematisation of power relations characteristic of a specific socio-historical plot, on the other.

The first such frame rests on the biological model of sex education (Felitti 2011). It focuses on the need to prevent the risks of sexuality in adolescence, a period in life seen to be 'threatened' by unwanted pregnancy, the transmission of disease, and, when articulated within a human rights paradigm, sexual/physical abuse and genderbased violence.

The second framing is focused on questioning and dismantling the power relationships that emerge in the social network that exist in society (Barrancos 2017; Maffia 2016). Its main objective is to reveal the symbolic and material inequalities that cut cross gender differences in society. However, within this focus, we can find certain 
tensions and contradictions around what a 'gender perspective' is understood to be. Some programmes conceive of gender relations in the context of a social inequality that needs to be questioned (Lakoff 2004), others view gender as a descriptive category that helps to explain differences between men and women, which maintains heteronormativity (Tannen 1994).

Sex education is a topic of public interest in the in the Latin American region (Vidal Velis 2011). The discourse of human rights was fundamental to installing the notion of integral sexuality and extending the biomedical field into other dimensions (social, historical, political, economic, ethical, psychological, cultural). However, the discourse of prevention has been the main argument for justifying the inclusion of the topic of sexuality in the school curriculum, and it has been reflected in the materials produced for its implementation in the pedagogical practice context (Dvoskin 2017). On the other hand, if the initiatives developed in each of these countries provide an extension of rights in terms of gender and sexuality, many of the proposals have put the focus on the individual responsibility of young people without considering the social and cultural context in which their behaviour originates, creating a mere illusion of freedom and autonomy around individual behaviour (Estupiñan Serrano 2011).

On the other hand, advances in the expansion of sexual and reproductive rights in Latin America have been met with a corresponding rise in resistance movements. The central actors in these movements continue to be religious organizations that see their traditional worldviews threatened by these new sexual and reproductive rights (Vaggione 2013). The continuing advance of evangelism in the region has made evangelical institutions interlocutors for national governments. Exponents of evangelism have publicly demonstrated against the inclusion of sex education in school curricula and different groups have emerged in opposition to sex education, most notable among which are the 'Con Mis Hijos No Te Metas' and 'Escola sem Partido'. Their efforts to restrict the circulation of gender and sexuality issues in the private sphere is draws support from neoliberal forces, which seek to prioritise individual rights (Faur 2020).

However, alongside religious actors, these movements also include lawyers, political officials, and experts in the field of reproductive health, whereby they acquire a (socially more) heterogeneous character, with an overlap between the religious and the secular (Morán Faúndes 2017). In our analysis, we will observe how this heterogeneity develops on the level of discourse. 


\section{NV STATI / ARTICLES}

\section{Method}

Our research employs a qualitative perspective because we consider discourse analysis a way of conducting a social analysis (Raiter 2008). This assumption is based on the idea that the use of language is a social practice (Fairclough 2004), and language use not only reflects the world it names, it also has a constitutive effect on that reality, to which it grants value and meaning. Therefore, the analysis of language needs to take into account the socio-historical conditions in which the discourses circulate, both the immediate contextual conditions and the more general social, political, cultural and economic conditions. Discourse analysis is in this way a useful tool for investigating the beliefs and representations that underlie these arguments and that configure the framework of what is thinkable in a given society (Angenot 2015).

In this sense, we consider discourse analysis a useful framework with which to examine the ideological content that circulates socially (Fairclough 2004; Wodak 2015). Thus, even though it is possible to find anti-gender movements in the past, they are essentially a new form of resistance in terms of their modalities of organisation, their practices, and the discursive how they position. These characteristics configure new discourses that seek to address wider audiences and more heterogeneous than traditional conservative groups (Kuhar, Zobec 2017). The characterisation of this type of discourse in Brazil and Argentina is important for analysing this movement in Latin America and how it is framed in the network of movements of this kind that circulate in the northern hemisphere.

The aim of our investigation is identify the patterns and specific features of these movements in Latin America. Specifically, in this article, we analyse the representations of gender and sexuality that are mobilised in the political sphere and the role that is attributed to the school institution in these topics. We therefore analysed the bills and parliamentary debates that took place about Escola Sem Partido (ESP) in Brazil between 2014 and 2017, and about Interrupción Voluntaria del Embarazo (IVE) in Argentina in 2018. We focus exclusively on the speeches of the legislators who spoke out in favour of the ESP project in Brazil and against the IVE in Argentina, because those are positions that are opposed to the expansion of rights relating to gender and sexuality, so these opponents function as the spokespersons - more or less explicitly - of anti-gender movements in the parliamentary debates.

We chose these debates because they both they both put the role of formal education centre stage. On the other hand, though 'gender ideology' was rarely mentioned during the parliamentary debates, once the debates were over the term spread widely on in the mass media and social networks (Dvoskin, Estivalet 2020). We therefore consider these debates to be a determining factor in creating the conditions for the social circulation of this term in Brazil and Argentina. 


\section{Corpus analysis}

\section{Escola Sem Partido (ESP)}

The Escola Sem Partido Movement (ESP), created in 2003 in Brazil, is based on movements such as No Indoctrination and the Campus Watch, which exist in Australia, the United States, and Canada. According to Espinosa and Queiroz (2017), Edgar Mizrahi' , a supporter of 'uribismo'6, is the most prominent representative of the Creation Studies Institute (CSI) in Latin America, which translates into Spanish materials to combat so-called indoctrination in public schools. The founder and leader of ESP, Miguel Nagib7, claims to have been inspired by the group of American parents and students associated around No Indoctrination.org, which aims to end the indoctrination or ideologisation in schools (Dvoskin, Estivalet 2020). However, while defending neutrality as a solution to the 'abuse of freedom to teach', ESP does not try to remain neutral, as we will see below. ESP has opposed 'Marxist indoctrination' from the time of its founding. According to Miguel (2016: 601), the combination of a denunciation of Gramscianinspired Marxist indoctrination with opposition to 'gender ideology' is consistent with the ESP's opportunist approach. With attacks, virtual actions, videos, installations in public spaces, and partnerships with 'icons' of the Brazilian conservative community, this union of union of an opposition to gender ideology with an opposition to Marxist indoctrination came about thanks to the work of propagandists from the extreme right, for whom the decline of conventional sexual morality is part of a communist strategy.

In this context, ESP organises itself through the following steps: a) it develops a website; b) it distributes publicity materials that propagate hate speech; c) it encourages people to denouce so-called ideological content, teaching materials, and the views and behaviour of teachers in the transmission of knowledge; and d) it introduces bills in different legislative chambers' Law Projects. The work of the ESP can be classed as operating on two fronts: the first is as an informal association of parents, students, and counsellors; and the second is the legislative environment. In addition, the founders of the ESP believe that the separation between training and content is necessary and disregard the difference between the act of educating and the act of indoctrinating. For the ESP, the teacher is not an educator. We can see this when the main text of the legislation it is backing proposes that a poster be hung in all primary and secondary education classrooms listing the following duties of a teacher (ESP 2021):

\footnotetext{
${ }^{5}$ President and founder of the Reformed Presbyterian Church of Colombia.

${ }^{6}$ Movement to support the government policies of Alvaro Uribe Vélez.

7 Miguel Nagib, a follower of Catholicism, has been the Attorney of the State of São Paulo in Brasília since 1985.
} 


\section{NV STATI / ARTICLES}

1. Teachers will not take advantage of the captive audience of students to promote their own ideological, religious, moral, political and party interests, opinions, conceptions, or preferences.

2. Teachers will not favour or harm students because of their political, ideological, moral, or religious convictions, or lack thereof.

3. Teachers will not carry out political party propaganda in the classroom nor will they encourage their students to participate in demonstrations, public events, and marches.

4. When dealing with political, socio-cultural, and economic issues, teachers will present students in a manner that is fair - that is, that gives equal depth and seriousness to - the main competing versions, theories, opinions, and perspectives on these issues.

5. Teachers will respect the right of parents to have their children receive a moral education that accords with their own convictions.

6 . Teachers will not allow the rights guaranteed in the previous items to be violated by the action of third parties within the classroom.

In this perspective, the act of educating would then be the responsibility of the family and religion, while teachers would limit themselves to instruction, which in the discourse of Escola sem Partido is equivalent to imparting neutral knowledge, without mobilising values or discussing the social reality of of what is being taught (Penna 2017).

It is clear, therefore, that the movement is in contradiction with itself because it is advocating for the teacher to play an impartial role as the mere transmitter of content to students as passive recipients. Through this thinking, ESP reveals its alignment with the political right, behavioural conservatism, and cultural reactionism (Demier 2017). Duarte (2018: 139-140) warns that contrary to what his advocates advocate, this movement is not trying to defend schools from party propaganda or ideological constraints. Its real purpose is to create an environment of ideological, ethical, and political censorship of teachers, curricula, and educational materials in order to subject the public school to the dictates of the most reactionary and irrational worldviews in contemporary society.

According to Penna (2017), the ESP has four characteristic focal points: 1) their concept of schooling; 2) disqualifying teachers; 3 ) engaging in fascist discursive strategies; and 4) defending parents' authority over their children. Arguments made in support of the actions of the ESP, we can classify them as follows: a) schools must be neutral; b) a student is a 'blank slate'; c) parents have the right to educate their children according to their values; d) schools support gender ideology; and e) teachers indoctrinate.

In 2013, religion started to be used as an instrument of pressure and political 
dispute in the state arena, as well as strengthening the ESP. Different religious deputies linked to the Parliamentary Fronts (Evangelical, Catholic, and the Front in Defence of the Family), started to support then Deputy Jair Bolsonaro in his attacks on the Ministry of Education (MEC), which, at the time, sought to promote respect for sexual diversity with the 'School Without Homophobia Project'. This material was called 'a gay kit' by conservative parliamentarians, just as the discussion of the theme on sexuality within schools came to be called 'gender ideology' by the ESP (Estivalet 2021). These arguments put wind in the sails of the ESP but they also began to present the work of teaching in a threatening light, so that parents started to be afraid that their children would come to contact with content related to sex education. Between 2014 and 2017, at least nine federation units introduced bills related to the Escola sem Partido programme. At the municipal level, dozens of other cities are in the process of passing bills. At the state level, only the state of Alagoas has approved such legislation, with he adopt of the so-called 'Free School' law (Act no. 7.800/2016). Other cities in the country have also passed laws with similar themes.

\section{Interrupción Voluntaria del Embarazo (IVE)}

In Argentina, the first parliamentary debate on the bill for the IVE was held in 2018. On June 13, the bill obtained the majority of votes in the Lower House of Congress, with 129 votes in favour of it, 125 against, and 1 abstention. However, almost two months later, on August 8 , it was rejected in the Senate, with 38 votes against the bill, 31 in favour of it, 2 abstentions, and 1 absence.

There were a couple of peculiarities about this debate, both in terms of the voting and in the arguments developed by the legislators to base their vote. Strictly regarding voting, it broke with political party logic: except for the 'Frente de Izquierda' (Left Front) bloc that voted entirely in favour of sanctioning the bill, the rest of the party blocks (had members who) voted in favour and against.

On the other hand, in the arguments, we observe a paradoxical fact: those who voted in favour of the bill and those who voted against it highlighted the importance of implementing sex education in schools. This fact put the school institution and the functions it must fulfil in society at the focus of the discussion and made it clear that, beyond the fact that since 2006 there has been an Educación Sexual Integral (Comprehensive Sexual Education) law in Argentina, there continues to be a dispute, both in the mass media and in the pedagogical sphere, over what modalities the schools should adopt and what content the schools should teach (Dvoskin 2015). In particular, it is striking that the deputies who voted against the IVE have claimed sex education in schools because their positions are usually close to that of the Catholic Church, whose main exponents have opposed different public policies sanctioned 


\section{NV STATI / ARTICLES}

in Argentina in recent decades that have sought to expand rights relating to gender and sexuality (Esquivel 2013).

However, when analysing the interventions of the deputies opposed to the IVE bill, we found that in the parliamentary debate they moved away from the religious discourse to base their positions. Instead, they relied on legal and scientific discourse:

7. If we are going to have this debate in good faith, there are two issues that we cannot ignore, which constitute the central point of all this. The first one pertains to the moment when life begins, and the second one is connected to the moment when a life becomes a person, i.e. the subject of rights. The first question can only be answered by science, which today tells us in an unquestionable way that from the point of fertilisation there is a life, an individual, a life that is different from that of the mother, with its own genetic load and its own DNA sequence. Then comes the legal system, which recognises that in that life in gestation, in that subject yet to be born, there is a human person, and the state owes him/her recognition and protection of his/her rights. This is what Article 19 of the Civil and Commercial Code states (Deputy Incicco: 157). ${ }^{8}$

Deputy Incicco takes up the legal and scientific discourses as representing the voices of authority to establish when there is life and when there is a person. As we pointed out in the introduction of this article, a characteristic of the anti-gender movements in Latin America is that they legal and scientific discourses in place of religious discourse (Vaggione 2013). Science is assimilated into a positivist paradigm that presents data as natural phenomena, devoid of any relation to the social conditions in which they take place (Habermas 1982). Thus, it is configured as a true, objective, transparent discourse, in opposition to ideology, which is associated with subjectivity and totalitarianism:

8. From the moment of conception a new set of DNA begins to exist ths is separate/distinct from that of the parents; there is a new human being, who is unique and concrete. This is a biological fact and not a subjective opinion. To ignore this biological reality and add cultural reasons, is to deny a scientific fact (Mr. Zamarbide: 138).

Consequently, formal education appears as the main tool for transmitting this 'neutral' knowledge. Sex education in schools is presented as a space for the transmission of information to students, who must internalise this knowledge so as not to experience the sufferings of the practice of abortion:

9. Protection must start with sex education and the various mechanisms and

\footnotetext{
${ }^{8}$ All the examples were taken from the stenographic version of the session journal of the Lower House of Representatives, Meeting 8 (6/13/18). After each fragment, we include, in parentheses, the name of the deputy responsible for the presentation and the page number of the journal.
} 
means to incorporate knowledge and values about the processes of conception and pregnancy. Undoubtedly, it is the responsibility of the state to assume this protective role, making available to all women different tools that guarantee their protection (Mr. Baldassi: 207).

According to the deputies opposed to the IVE bill, the purpose of sex education is to prevent the unwanted consequences such as abortion or sexually transmitted diseases. Indeed, the topic of sexuality is reduced to its biological content. Sexuality becomes is portrayed as a risk activity and education appears is presented as a method of prevention and protection:

10. Comprehensive sex education is the sincerest way of dealing with the problems that exist in our society, it is a concrete and real way of preventing situations that harm those who are the most vulnerable and to build an egalitarian society, where the elimination of a life is not a regrettably accepted practice (Mr. Olivares: 103).

In this way, the representation of sex education as an argument against the IVE bill configures the scientific discourse - specifically, the biomedical discourse - as the only discourse that has the legitimacy to address this problem.

Thus, a 'banking concept' of education is reproduced (Freire 1994), according to which the teacher's role is to transmit curricular content to the students, who receive this content uncritically and incorporate it into their previous knowledge without any reflection. Criticism on the part of the student is impossible when education is presented as the transmission of fixed content, pre-established in advance by specialised agents (Illich 2011), in this case, specialists in the field of health.

Deputies against the IVE bill conceive of sex education exclusively as a method of preventing the unwanted consequences of sexual activity. This representation leaves out all the content about gender and sexuality that relates to pleasure, autonomy, or even violence. This representation/conception of sex/sex education is consistent with the content put into circulation by the collective 'Con Mis Hijos No Te Metas', the main anti-gender movement in Argentina. Faur (2020) points out that the opposition of this movement to the implementation of sex education adopted two types of modalities. On the one hand, in the cultural field, it urged citizens to mobilise and spread messages through social networks, whose main focus of attack was 'gender ideology'. ${ }^{9}$ On the other hand, at the institutional level, it developed strategies to prevent sex education from being taught in schools, especially through the 'I do not authorize' campaign, which involved sending parents a model letter that establishes that the Comprehensive Sex Education law is illegal, based on arguments that refer to the Argentinian national constitution.

\footnotetext{
9 Through social networks, the CMHNTM movement disseminated a material that was widely circulated in August 2018 in Argentina called "Gender ideology. Myths and truths".
} 


\section{NV STATI / ARTICLES}

Although this is a movement that acts as a spokesperson for the positions of portions of the Catholic and evangelical churches on issues of gender and sexuality, as were the deputies who opposed the IVE bill in the parliamentary arena, their positions are given by legal and scientific discourses. In this way, they move away from the religious discourse, a discursive operation that allows them to address a broader and more heterogeneous public.

\section{Discussion and conclusion}

In this article, we characterised the discourses that in Brazil and Argentina contributed to stopping the expansion of rights relating to matters of gender and sexuality. This resistance employs the rhetoric of a common sense viewpont that promotes a strictly biological conception of sexuality, a paradigm that maintains a binary classification of gender. At the same time, the discussion of sex education policies in schools makes parents as the principal addressees. The main strategy used to reach them involved awakening fear and moral panic, a tool that unites diverse sectors of society that are not usually drawn to religious discourse. This moral panic is built by reducing gender and sexuality issues to the unwanted consequences of sexual activity, such as the transmission of STDs, unwanted pregnancy, or abortion. This reduction uses the anti-gender discourse to present formal education as a tool for preventing these unwanted circumstances and omitting any gender-related content that questions the dominant social order. Indeed, sex education is restricted to the right to prevent consequences.

Consequently, the discourse of anti-gender movements in Brazil and Argentina strives school knowledge as mere information. This representation allows the reproduction of a pedagogical model in which the teacher must transmit apparently neutral content, scientifically validated, that the student must ingest and reproduce without critical reflections/interpretation. This establishes an opposition between science and ideology: one is on the side of truth, objectivity, and transparency; while the other is on the side of lies, manipulation and indoctrination.

Indeed, according to the theoretical framework we presented at the beginning of the article, we may conclude that the anti-gender discourse in Brazil and Argentina shares with religious discourse its precepts relating to gender and sexuality matters. However, the current discourse of this movement is not positioned grounded in religious discourse. Instead, it appeals to scientific and legal discourses as a mechanism for assigning legitimacy to its arguments and as a way of attracting a wider audience.

The movement's current discourse is also applied to and used grant legitimacy to new configurations in the disputes around gender and sexuality issues in Latin 
America (Careaga Pérez 2019) and it joins a network of anti-gender movements that are also prevalent in the northern hemisphere (Kuhar, Zobec 2017).

The discourse of anti-gender movements reveals a mentality that seeks to nullify difference, mainly because they reject the rights of political minorities in today's society. Thus it depicts a character that besides being ideological (an ideology that is understood as something bad and that would not be inherent to human nature) is mistaken, does not correspond to the truth, and reflects an intolerance of differences, thereby posing a threat to freedom and democracy.

As we showed in the analysis section, the discourse of anti-gender movements uses a characteristic stratagem of fascist discourse: persecuted innocence, which refers to the existence of a potential, constant, and real threat. According to Adorno (2015), this distortion serves two purposes: the first purpose is to name the supposed danger as a threat to all; and the second is to portray the aggressiveness that is used against this threat as a form of self-defence. In this sense, we may consider that the objective of these movements is to make the debate in the public space about gender equity and sexual diversity unfeasible, reiterating the naturalisation of gender inequality and heteronormativity, which, ultimately, will lead to the continuation of discriminatory practices both at school and in society in general.

Thus, mercantile fundamentalism joins forces with religious fundamentalism and advances towards intolerance, and even denies liberal principles, the way both Nazism and Fascism. Anti-gender movements reject the idea that the act of educating is an intrinsic part of the action of teaching and denies students the ability to develop a critical reading of reality, thereby preventing them from constituting themselves as social actors.

\section{References}

Adorno, T. 2015. Ensaios sobre psicologia social e psicanálise. São Paulo: Unesp.

Amaya, J. 2017. La tormenta perfecta: ideologia de género y articulación de públicos.

Sexualidad, Salud y Sociedad - Revista Latinoamericana 27: 149-171.

Angenot, M. 2015. O discurso social e as retóricas da incompreensão. São Carlos: EDUFSCar. Barrancos, D. 2017. Feminismos y agencias de las sexualidades disidentes. Pp. 1-16 in Faur,

E. (ed.). Mujeres y varones en la Argentina de hoy: Géneros en movimiento. Buenos Aires: Siglo XXI.

Barzotto, C., F. Seffner. 2020. Escola sem Partido e sem gênero: redefinição das fronteiras público e privado na educação. Rev. FAEEBA - Ed. e Contemp 29 (58): 150-167.

Béraud, C., P. Portier. 2015. Métamorphoses catholiques: Acteurs, enjeux et mobilisations depuis le mariage pour tous. Paris: Editions de la Maison des Sciences de l'Homme. Campana, M. 2020. Políticas anti-género en América Latina: Argentina. Brazil: Género \& Política en América Latina. 


\section{NV STATI/ ARTICLES}

Careaga Perez, G. 2019. Sexualidad, religión y democracia en América Latina. México: Universidad Autónoma de México.

Corrêa, S., I. Kalil. 2020. Políticas antigénero en América Latina: Brasil. Rio de Janeiro: Observatorio de Sexualidad y Política (SPW).

Demier, F. 2017. Depois do golpe: a dialética da democracia blindada no Brasil. Rio de Janeiro: Mauad X.

Duarte, N. 2018. O Currículo em Tempos de Obscurantismo Beligerante. Revista Espaço do Currículo 2 (11).

Dvoskin, G. 2015. Medios y realidad: formaciones discursivas en disputa. Signo y Seña 27 (1): 143-169, https://doi.org/10.34096/sys.n27.3191.

Dvoskin, G. 2017. El discurso de la Educación sexual en la Argentina: Sentidos legítimos y sentidos silenciados. Cadernos de Linguagem e Sociedade 18 (1): 158-177, https://doi. org/10.26512/les.v18i1.1572.

Dvoskin, G. 2021. Between the Urgent and the Emerging: Representations on Sex Education in the Debate for Abortion Legalization in Argentina. Frontiers in Sociology 6 (1): 1-13, https://doi.org/10.3389/fsoc.2021.635137.

Dvoskin, G, A. G. Estivalet. 2020. Gênero e sexualidade: (Ou) Posições sobre a educação sexual. Interritórios 6 (10): 48-72, https://doi.org/10.33052/inter.v6i10.244893.

ESP. 2021. Programa Escola sem Partido. Brazil: ESP. Retrieved 7/28/2021 (https://www. escolasempartido.org/programa-escola-sem-partido/).

Espinosa, B. S., F. C. Queiroz. 2017. Breve análise sobre as redes da Escola sem Partido. Pp. 49-62 in Frigotto, Gaudêncio. Escola 'sem' Partido: esfinge que ameaça a educação e a sociedade Brasileira. Rio de Janeiro: LPP/UERJ.

Esquivel, J. 2013. Cuestión de educación (sexual): Pujas y negociaciones político-religiosas en la Argentina democrática. Buenos Aires: CLACSO.

Estivalet, A. G. 2021. Neoliberalism and Conservatism: Findings about the Escola sem Partido. Exlibris 10: 140-155.

Fairclough, N. 2004. Analysing Discourse. Textual Analysis for Social Research. London and New York: Routledge.

Faur, E. 2012. El desafío de la educación sexual. La Plata: UNIPE.

Faur, E. 2020. Educación sexual integral e 'ideología de género' en la Argentina. Forum 51 (2): 57-61.

Felitti, K. 2011. Educación sexual en la Argentina: Políticas, creencias y diversidad en las aulas. Pp. 113-133 in Marquet, A. (ed.). Hegemonía y desestabilización: Diez reflexiones en el campo de la cultura y la sexualidad. México: Fundación Arco Iris and Ediciones EON.

Felitti, K., M. S. Prieto. 2018. Configuraciones de la laicidad en los debates por la legalización del aborto en la Argentina: discursos parlamentarios y feministas (20152018). Salud colectiva 14 (3): 405-423.

Freire, P. 1994. Pedagogia do oprimido. Rio de Janeiro: Paz e terra. Illich, I. 2011. La sociedad desescolarizada. Buenos Aires: Godot.

Junqueira, R. 2018. A invenção da 'ideologia de gênero': a emergência de um cenário político-discursivo e a elaboração de uma retórica reacionária antigênero. Revista Psicologia Política 18 (43): 449-502. 
Kováts, E., Põim, M. (eds.). 2015. Gender as Symbolic Glue: The Position and Role of Conservative and Far Right Parties in the Anti-Gender Mobilization in Europe. Brussels: Fondation for European Progressive Studies and Friedrich-Ebert-Stiftung Budapest.

Kuhar, R. 2015. Konec je sveta, kakršnega poznamo: populistične strategije nasprotnikov Družinskega zakonika. Časopis za kritiko znanosti 260: 118-132.

Kuhar, R., A. Zobec. 2017. The Anti-gender Movement in Europe and the Educational Process in Public Schools. C-E-P-S Journal 7 (2): 29-46.

Laclau, E. 2013. A razão populista. São Paulo: Três Estrelas.

Lakoff, R. 2004. Language and Woman Place. Texts and Commentaries. New York: Oxford University Press.

Lopes Louro, G. 2018. Currículo, género y sexualidad. Lo 'normal', lo 'diferente' y lo 'excéntrico'. Descentrada 3 (1): 1-7.

Kalinowski, S., J. Gasparri, S. I. Pérez, F. Moragas. 2020. Apuntes sobre lenguaje no sexista e inclusivo. Rosario: UNR Editora.

Mayer, S., B. Sauer. 2017. 'Gender Ideology' in Austria: Coalitions around an Empty Signifier. Pp. 23-40 in Kuhar, R., D. Paternotte (eds.). Anti-gender Campaigns in Europe. Mobilizing against Equality. London: Rowman \& Littlefield.

Miguel, L. F. 2016. Da 'doutrinação marxista' à 'ideologia de gênero' - Escola sem Partido e as leis da mordaça no Parlamento brasileiro. Revista Direito \& Práxis 7 (15): 590-621.

Moragas, M. 2020. Políticas antigénero en América Latina: el caso de la Organización de los Estados Americanos (OEA). Rio de Janeiro: Observatorio de Sexualidad y Política (SPW).

Morán Faúndes, J. M., M. A. Peñas Defagó, C. Sgró Ruata, J. M. Vaggione. 2019. La resistencia a los derechos sexuales y reproductivos. Las principales dimensiones del neo-activismo conservador argentino In Careaga Pérez, G. (ed.). Sexualidad, religión y democracia en América Latina. México: Universidad Autónoma de México.

Morgade, G. 2017. Contra el androcentrismo curricular y por una educación sexuada justa. Revista Internacional de Educación para la Justicia Social 6 (2): 49-62.

Moura, C. G., P. F. Silva. 2020. Os estratagemas psicológicos utilizados pelo programa do Movimento Escola sem Partido. Rev. FAEEBA - Ed. e Contemp. 29 (58): 270-289.

Mudde, C. 2007. Populist Radical Right Parties in Europe. Cambridge: Cambridge University Press.

Penna, F. 2017. Escola sem Partido como chave de leitura do fenômeno educacional. Pp. 35-49 in Frigotto, G. (eds.). Escola 'sem' partido: esfinge que ameaça a educação e a sociedade brasileira. Rio de Janeiro: UERJ.

Radi, B., C. Pagani. 2021. ¿Qué perspectiva? ¿Cuál género? De la educación sexual integral al estrés de minorías. Praxis educativa 25 (1): 1-12, https://dx.doi.org/10.19137/ praxiseducativa-2021-250116.

Raiter, A. 2008. Analizar el uso lingüístico es analizar ideología. Pp. 21-41 in Raiter, A., J. Zullo (eds.). La caja de Pandora. Buenos Aires: La Crujía.

Tannen, D. 1994. Gender and Discourse. New York: Oxford University Press.

Vaggione, J. M. 2013. Laicidad y sexualidad. México: Universidad Autónoma de México. Wodak, R. 2015. The Politics of Fear: What Right-Wing Populist Discourses Mean. London: Sage. 
(c) BY-NC Anelise Gregis Estivalet, Gabriel Dvoskin, 2021.

(c) BY-NC Institute of Sociology of the Czech Academy of Sciences, 2021.

Anelise Gregis Estivalet, $\mathrm{PhD}$, is a social scientist. She is a professor at the Faculty of Education of the University of Brasília. Her research interests are in gender, education, public policies, violence, youth, and the monitoring and evaluation of public policies.

Contact e-mail: anegregis@gmail.com.

Gabriel Dvoskin, PhD. He is a professor at the Faculty of Philosophy and Linguistics at the University of Buenos Aires. His research focuses on discourse, gender and education. Contact e-mail: gabidvoskin@gmail.com. 